\title{
Integratie en depressie De relatie tussen sociaal-culturele integratie en depressieklachten bij Turkse en Marokkaanse Nederlanders
}

\author{
Roos van der Zwan \& Jochem Tolsma ${ }^{1}$
}

\begin{abstract}
Summary
Integration and depression

The relationship between social-cultural integration and symptoms of depression among Turkish and Moroccan migrants in the Netherlands
\end{abstract}

In this study we described differences in the prevalence of depressive symptoms among first and second generation Turkish and Moroccan migrants and Native Dutch. Furthermore, we scrutinized to what extent differences in socio-cultural integration are related to differences in the prevalence of depressive symptoms. Hypotheses are tested using the NEtherlands Longitudinal Lifecourse Study (NELLS). Results show that first and second generation Turkish migrants and first generation Moroccan migrants experience more depressive symptoms than Native Dutch. For migrants, maintaining weak and strong ties with native Dutch is related to less symptoms of depression. Ethnic and national identification protect against depressive symptoms. Living according to Islamic rules is not related to depressive symptoms. We did not observe that bicultural migrants - migrants who have strong ethnic and national identifications and migrants who maintain social relationships with ethnic ingroup members and with native Dutch - experience more depressive symptoms. Differences in socio-cultural integration hardly explain differences in depressive symptoms among first and second generation Turkish and Moroccan migrants.

\section{Inleiding}

Psychische klachten, zoals stemmings- en persoonlijkheidsstoornissen, komen vaker voor onder Turkse en Marokkaanse Nederlanders dan onder de autochtone bevolking. Dit blijkt zowel uit klinische studies 
als uit bevolkingsstudies. Zo concludeert Driessen (2011) op basis van het Permanent Onderzoek Leefsituatie dat ruim 30\% van de Turkse en Marokkaanse Nederlanders een minder goede geestelijke gezondheid heeft. Onder de autochtone Nederlanders zou dit slechts 13\% zijn. Nederland vormt in dit verband geen uitzondering, ook uit de internationale literatuur komt het beeld naar voren dat migrantengroepen vaker last hebben van psychische klachten dan de autochtone bevolking (Koneru e.a., 2007).

Specifieke studies naar depressie - die een stuk zeldzamer zijn (Carta e.a., 2005; Swinnen \& Selten, 2007) - laten zien dat migranten in Nederland eveneens een groter risico op depressie(klachten) hebben dan autochtone Nederlanders (Selten \& Nolen, 2003; Selten e.a., 2012; De Wit e.a., 2008; Van der Wurff e.a., 2004). Zo komen depressieve symptomen ongeveer twee tot vier keer zo vaak voor onder respectievelijk oudere Marokkaanse Nederlanders en Turkse Nederlanders dan onder autochtone ouderen (Van der Wurff e.a., 2004). Maar ook migrantenjongeren kampen relatief vaak met deze klachten (Bengi-Arslan, Verhulst \& Crijnen, 2002; Gijsberts \& Dagevos, 2009; Janssen e.a., 2004; SCP, 2002). Dit beeld wordt erkend door Turks-Nederlandse professionals. In een open brief aan de Volkskrant uiten zij hun bezorgdheid over de problemen onder Turks-Nederlandse jongeren. Deze professionals beweren dat veel Turkse jongeren frustraties, een gebrek aan zelfvertrouwen en psychische klachten hebben (Sevincer, Daldal \& Yabas, 2010).

Hoewel eerder onderzoek dus overtuigend laat zien dat depressieklachten vaker voorkomen onder migrantengroepen dan onder de autochtone bevolking, blijft het onduidelijk hoe vaak deze klachten voorkomen. Klinische studies naar de prevalentie van depressie(klachten) (Bhugra, 2004; Selten \& Nolen, 2003; Selten e.a., 2012) kennen hun beperkingen, doordat het onduidelijk is in welke mate het vragen om, en krijgen van, hulp bij een vermoeden van een depressie afhangt van etnische herkomst. Bevolkingsstudies maken veelal gebruik van meetinstrumenten die symptomen van depressie in kaart brengen middels zelfrapportage (zie voor een uitzondering: De Wit e.a., 2008). Hiermee kan echter geen klinische diagnose van depressie worden gesteld volgens de richtlijnen van de Wereldgezondheidsorganisatie (WHO, 1993) of volgens de DSM-IV criteria (APA, 1994). Bovendien zijn in bevolkingsstudies etnische minderheidsgroepen vaak ondervertegenwoordigd en vormen zij een selectieve groep. Zo werden in eerder onderzoek bijvoorbeeld enkel migranten uit één bepaalde stad ondervraagd, alleen ouderen, of slechts één etnische groep (Aichberger e.a., 2010; De Wit e.a., 2008; Van der Wurff e.a., 2004). Ons inziens is een ander belangrijk hiaat in het Nederlandse (en internationale) onderzoek dat mogelijke verschillen tussen de eerste en tweede generatie migranten in depressieklachten onderbelicht zijn 
gebleven. Zo bleek in een recente meta-analyse naar het voorkomen van stemmingsstoornissen onder migranten het maken van een onderscheid tussen de eerste en tweede generatie migranten niet mogelijk (Swinnen \& Selten 2007). ${ }^{2}$

In dit artikel pogen we een bescheiden bijdrage te leveren aan de beschrijving van het voorkomen van depressieklachten onder Turkse en Marokkaanse Nederlanders van de eerste en tweede generatie. We zullen deze prevalentie van depressieklachten vergelijken met de prevalentie onder de autochtone bevolking. We maken daartoe gebruik van gegevens afkomstig uit de NEderlandse Levensloopstudie (NELLS; De Graaf, Kalmijn, Kraaykamp \& Monden, 2010). In de vragenlijst van de NELLS zijn de zestien negatief geformuleerde items uit de Center for Epidemiologic Depression Scale (CES-D) (Radloff, 1977) opgenomen. Met deze zestien items wordt in kaart gebracht of men zich depressief voelt (Depressed Affect), of men symptomen van depressie laat zien (Somatic-Retarded Activity) en of er problemen zijn met sociale relaties (Interpersonal Affect). Aangezien deze drie subdimensies onderling samenhangen, is het volgens Schroevers e.a. (2000) zinvoller om ze als één overkoepelende dimensie te interpreteren, namelijk als 'Depressed Affect'. De CES-D is de meest gebruikte manier om via zelfrapportage symptomen van depressie te identificeren. De CES-D kent goede psychometrische eigenschappen onder zowel jongeren als ouderen en onder zowel de autochtone bevolking als onder migrantengroepen (Spijker e.a., 2004). Waren migranten in eerdere bevolkingsonderzoeken veelal ondervertegenwoordigd, in de NELLS zijn Turkse en Marokkaanse migranten (tussen de 16 en 45 jaar) juist oververtegenwoordigd. Respondenten zijn bovendien niet afkomstig uit één enkele gemeente, maar uit 35 verschillende gemeenten. Tot slot laat de grootte van de steekproef (onze analyses hebben betrekking op 4401 respondenten, waaronder 1222 migranten van de eerste en 698 migranten van de tweede generatie) een vergelijking toe tussen de eerste en tweede generatie. De eerste onderzoekvraag die in deze bijdrage wordt beantwoord, luidt:

(1) In hoeverre komen depressieklachten voor onder Marokkaanse en Turkse Nederlanders van de eerste en tweede generatie in vergelijking met de autochtone Nederlandse bevolking?

Ouderen, vrouwen en mensen met een lage sociaaleconomische status hebben meer last van psychische klachten dan jongeren, mannen en mensen met een hoge sociaaleconomische status. Dat etnische minderheidsgroepen gemiddeld genomen een lager opleidingspeil hebben en een slechtere positie op de arbeidsmarkt bekleden, verklaart dan ook ten dele de relatief hoge prevalentie van psychische klachten. Toch blijven de verschillen geprononceerd, zelfs nadat men hier rekening mee houdt 
(Aichberger e.a., 2010; Missine \& Bracke, 2012; De Wit e.a., 2008; Van der Wurff e.a., 2004). Een mogelijk verklaring voor het relatief vaak voorkomen van psychische klachten zou volgens verschillende auteurs kunnen liggen in de acculturatie-ervaringen van migranten (Koneru e.a., 2007; De Wit e.a., 2008).

Onder acculturatie worden de culturele en psychologische veranderingen verstaan die optreden wanneer leden uit verschillende culturen met elkaar in contact komen (Berry, 1997). Als gevolg van migratie zullen migranten en hun kinderen in meer of mindere mate vasthouden aan de culturele waarden, normen en gebruiken van de herkomstgroep als wel in meer of mindere mate participeren in de ontvangende samenleving en de culturele waarden, normen en gebruiken hiervan overnemen. Berry $(1997,2005)$ onderscheidde vier acculturatiestrategieën: assimilatie (zwakke etnische identificatie en sterke participatie in ontvangende samenleving), integratie (sterke etnische integratie en sterke participatie in ontvangende samenleving), separatie (sterke etnische integratie en geen participatie in ontvangende samenleving) en marginalisatie (zwakke etnische identificatie en geen participatie in ontvangende samenleving).

Een grotere gerichtheid op de ontvangende samenleving zou de (dagelijkse) sociale interactie en toegang tot de (geestelijke) gezondheidszorg, indien nodig, vergemakkelijken. Dit zou tot de verwachting leiden dat een sterkere gerichtheid op de ontvangende samenleving zou samenhangen met minder depressieklachten. Aan de andere kant kan juist deze gerichtheid op de ontvangende samenleving ervoor zorgen dat minder sociale steun wordt ontvangen van de directe familie (die sterker vasthoudt aan de oorspronkelijke cultuur). Volgens Berry (2005) is de integratiestrategie - in het Nederlands vaak angeduid als 'integratie met behoud van eigen identiteit' - het beste voor het psychisch welbevinden van migranten. Aan de andere kant stellen auteurs dat juist het verkeren tussen twee culturen en daarmee het vervullen van verschillende - tegenstrijdige - sociale rollen (Goode, 1960) voor acculturatiestress kan zorgen en dit mogelijk leidt tot (symptomen van) depressie (Bughra, 2004; Rudmin \& Ahmadzadeh, 2001).

Het empirisch verband tussen (indicatoren van) acculturatie en depressieklachten is tot op heden allerminst duidelijk (Koneru e.a., 2007). ${ }^{3}$ Deze ambiguïteit wordt voor een belangrijk deel veroorzaakt, doordat onderzoekers acculturatie verschillend definiëren en operationaliseren. In deze studie erkennen wij dat acculturatie zowel de mate van gerichtheid op de eigen cultuur (of van diens ouders) betreft als de mate van gerichtheid op de ontvangende samenleving. Maar waar Berry $(1997,2005)$ gerichtheid op de eigen cultuur vooral tot uiting zag komen in etnische identificatie (cultural maintenance) en gerichtheid op de ont- 
vangende samenleving in sociale participatie (contact and participation), komt ons inziens in beide gevallen deze betrokkenheid tot uiting in (etnische of nationale) identificatie, attituden en gedrag. ${ }^{4}$ In dit artikel zullen wij niet expliciet de samenhang tussen de vier door Berry (1997, 2005) onderscheiden acculturatiestrategieën en het voorkomen van depressieklachten onderzoeken. Ons inziens in het informatiever na te gaan in hoeverre specifieke indicatoren van sociale integratie (contact met leden van de eigen etnische groep en contact met autochtonen) en van culturele integratie (identificatie met de eigen etnische herkomst en met Nederland, taalbeheersing, leven volgens de islam) samenhangen met het voorkomen van depressieklachten. Hierbij is het natuurlijk wel noodzakelijk rekening te houden met bekende determinanten van depressie zoals geslacht, leeftijd, opleidingsniveau en arbeidsmarktpositie. De tweede onderzoeksvraag van dit artikel luidt:

(2) In hoeverre hangen aspecten van sociale en culturele integratie samen met depressieklachten bij Marokkaanse en Turkse Nederlanders van de eerste en tweede generatie?

De tweede generatie kent logischerwijs heel andere acculturatie-ervaringen dan de eerste generatie. De tweede generatie heeft meer contact met autochtonen dan de eerste generatie (Gijsberts \& Dagevos, 2009), identificeert zich vaker meer met de ontvangende samenleving dan met de etnische herkomst van de ouders (Tolsma, Lubbers \& Gijsberts, 2012), en bij hen speelt de islam een minder belangrijkere rol in het leven dan bij eerste generatie Marokkaanse en Turkse Nederlanders (Maliepaard, Lubbers \& Gijsberts, 2010). Indien sociaal-culturele integratie samenhangt met het voorkomen van depressieklachten is het aannemelijk dat de prevalentie van depressieklachten anders is voor de tweede dan voor de eerste generatie. Het schaarse buitenlandse onderzoek naar de relatie tussen generatiestatus en depressie (Harker, 2001) laat echter geen duidelijke verschillen in depressieklachten tussen de eerste en tweede generatie zien. Volgens Harker (2001) zou dit komen doordat de tweede generatie weliswaar meer op de autochtone bevolking lijkt met betrekking tot structurele kenmerken (opleidingsniveau en arbeidsmarktpositie), maar juist minder religieus is en eerder sociale steun ontbeert. Voor Nederland is nog onduidelijk in welke mate indicatoren van sociaal-culturele integratie samenhangen met de mogelijke verschillen tussen de eerste en tweede generatie. Dit leidt tot de laatste onderzoeksvraag:

(3) In welke mate hangen aspecten van sociale en culturele integratie samen met (mogelijke) verschillen in de prevalentie van depressieklachten tussen de eerste en tweede generatie Marokkaanse en Turkse Nederlanders? 
Deze bijdrage bouwt voort op het werk van Van der Wurff en collega's (2004). Ook zij vroegen zich af of verschillen in prevalentie tussen etnische groepen in zelf gerapporteerde depressieklachten verklaard kunnen worden door bekende determinanten van depressie en factoren die samenhangen met acculturatie-ervaringen. Waar zij zich richtten op verschillen tussen autochtone en allochtone ouderen, focussen wij op een relatief jonge groep. Volgens Koneru en collega's (2007) zou het juist binnen deze groep mogelijk moeten zijn om de invloed van indicatoren van acculturatie waar te nemen. Hiernaast ligt in ons artikel de nadruk op de samenhang tussen generatiestatus en het voorkomen van depressieklachten, een aspect wat tot op heden onderbelicht is gebleven.

\section{Theorie en hypothesen}

\section{I Sociale integratie}

Sociale relaties beïnvloeden op verschillende manieren iemands welbevinden. Contact met familie, vrienden, kennissen en buurtgenoten vergroot de (ervaren) sociale steun die iemand bezit. Sociale steun in tijden van nood, of dat nu bestaat uit emotionele steun, het verstrekken van informatie of materiële goederen, draagt meestal bij aan een beter psychisch welzijn (social support mechanism). Een meer indirecte manier waarop sociale relaties iemands psychisch welbevinden beïnvloeden is dat sociale netwerken (of intermediërende groeperingen) houdingen en gedrag beïnvloeden die invloed kunnen hebben op het psychisch welbevinden. Denk hierbij aan iemands zelfwaarde, sporten of alcoholgebruik. Een gebrekkige sociale integratie en als gevolg hiervan niet weten hoe te gedragen, hangt negatief samen met psychisch welzijn (social integration mechanism; Cohen, 2004; Durkheim, 1951[1897]). Het is dan ook niet verrassend dat eerder onderzoek aantoont dat depressie(klachten) vaker voorkomen onder mensen met kleinere sociale netwerken en minder sterke bindingen (Berkman e.a., 2000; Kawachi \& Berkman, 2001) en wij verwachten dit verband te repliceren.

We merken op dat wij niet expliciet spreken van een causaal verband. Het ontberen van sociale relaties kan leiden tot een slechtere mentale gezondheid, maar andersom kunnen depressieklachten zorgen voor minder sociale contacten. Schaars longitudinaal onderzoek naar deze relatie lijkt overigens aan te tonen dat er voornamelijk sprake is van een causale relatie tussen sociale relaties naar depressieklachten (Peirce e.a., 2000). Bovendien hebben de geanalyseerde depressieklachten in dit artikel betrekking op de week voorafgaand aan het interview met de respondent (zie sectie: data en methoden), terwijl de vragen over sociale contacten betrekking hebben op een langere periode. Toch dient men 
terughoudendheid te betrachten bij het causaal interpreteren van deze relatie (Kawachi \& Berkman, 2001).

De focus van dit artikel is echter om na te gaan in welke mate acculturatie - het samenspel tussen de mate van gerichtheid op de eigen etnische groep en de gerichtheid op de ontvangende samenleving - samenhangt met depressieklachten. De vraag is dan ook of er voor Turkse en Marokkaanse Nederlanders een verschillende invloed uitgaat van sociale relaties met leden van de eigen etnische groep en met autochtone Nederlanders. Hier valt aan de ene kant te verwachten dat juist contact met de eigen etnische groep een positieve uitwerking zal hebben. Zij zullen mogelijk elkaars (overeenkomstige) problemen beter begrijpen dan iemand met een andere achtergrond en beter emotionele steun kunnen bieden. Anderzijds valt te verwachten dat juist contact met autochtone Nederlanders bescherming biedt tegen depressieklachten. Autochtone Nederlanders kennen de Nederlandse samenleving en haar structuur wellicht beter en zijn daardoor beter in staat relevante informatie te verstrekken die bijdraagt aan psychisch welbevinden.

Turkse en Marokkaanse Nederlanders hebben veelal zowel contacten met leden van de eigen etnische groep als met autochtone Nederlanders. Dit geldt in sterkere mate voor de tweede generatie dan voor de eerste (Gijsberts \& Dagevos, 2009). Een (etnisch) divers netwerk is waarschijnlijk het beste in staat om informatie aan te reiken met betrekking tot gezond gedrag, gebruik van gezondheidszorg en over hoe (psychische) risicosituaties te vermijden (Cohen, 2004). Contact met zowel leden van de eigen etnische groep als van de ontvangende samenleving past binnen de idee van 'integratie met behoud van eigen identiteit'. Volgens Berry $(1997,2005)$ zou, indien een samenleving openstaat voor etnische diversiteit en migranten zich welkom voelen, juist deze acculturatiestrategie bijdragen aan het psychisch welbevinden van migranten.

In het verleden werd de Nederlandse samenleving (samen met Canada) gezien als het prototype van de multiculturele samenleving waarin ruimte was voor 'integratie met behoud van eigen identiteit' (Entzinger, 2003). In het huidige integratiebeleid wordt een sterkere nadruk gelegd op het actief participeren van nieuwkomers in de maatschappij en wordt er in meer dwingende termen gesproken over (culturele) aanpassing aan de Nederlandse samenleving (Ministerie VROM/WWI, 2007; Coenders, Lubbers, Scheepers \& Verkuyten, 2008). Het is daarom niet vanzelfsprekend dat 'integratie met behoud van eigen identiteit' - en daarmee het zowel onderhouden van contacten met de eigen etnische groep als met autochtone Nederlanders - de beste acculturatiestrategie is. Ook volgens Vedder en Virta (2005) hangt de te prefereren acculturatiestrategie af van tijd en plaats. Het participeren in de ontvangende samenleving en tegelijkertijd contacten onderhouden met leden van de etnische her- 
komstgroep kan bovendien tot verschillende verwachtingen leiden over hoe men zich dient te gedragen. Volgens de Role strain theory kan, doordat men zich niet kan gedragen zoals men zich wil gedragen of verwacht wordt te gedragen, het psychisch welbevinden aangetast worden (Goode, 1960).

Uit de bovenstaande gedachtegang leiden we de volgende hypothesen af:

1a: Hoe meer sociale relaties Turkse en Marokkaanse Nederlanders onderhouden, hoe minder vaak zij depressieklachten rapporteren.

1b: Het onderhouden van sociale relaties met zowel leden van de eigen groep als met autochtone Nederlanders verzwakt het negatieve verband tussen sociale relaties en depressieklachten.

De tweede generatie heeft in vergelijking met de eerste generatie weliswaar meer contact met de autochtone bevolking, maar er is bij hen tevens vaker sprake van een gemengd netwerk (Gijsberts \& Dagevos, 2009). Het is dus vooraf moeilijk om te voorspellen hoe de verschillen in grootte en samenstelling van het sociaal netwerk tussen de generaties samenhangen met mogelijke verschillen in het voorkomen van depressieklachten tussen generaties.

\subsection{Culturele integratie}

Culturele integratie wordt door Dagevos (2001, p. 20) gedefinieerd als: "de mate waarin de cultuur van een allochtone groep "afwijkt" van die van de ontvangende samenleving, dan wel de mate van "culturele aanpassing" van een allochtone groep aan de cultuur van de ontvangende samenleving'. Etnische en nationale identificatie, het naleven van religieuze normen en taalbeheersing worden gezien als belangrijke indicatoren van culturele integratie. Tot op heden is het onduidelijk in hoeverre deze indicatoren van integratie samenhangen met het voorkomen van depressieklachten.

Volgens de self-esteem hypothese uit de sociale-identiteitstheorie (Brown, 2001; Tajfel \& Turner, 1979) zou naarmate men zich meer in positieve zin onderscheidt van andere groepen de eigenwaarde toenemen. Een sterke etnische identiteit zou hieraan kunnen bijdragen. Een sterke identiteit verschaft hiernaast duidelijkheid over de normen en waarden hoe men zich dient te gedragen en beschermt ook hiermee tegen psychische klachten (Durkheim, 1951[1897]; Thoits, 1983). Hoewel in de bestaande literatuur, voortbordurend op de sociale-identiteitstheorie, vooral de (positieve) relatie werd onderzocht tussen etnische identificatie en eigenwaarde (bijvoorbeeld: Umaña-Taylor e.a., 2002), zou een sterke etnische identificatie ook meer in het algemeen bijdragen aan psychisch 
welbevinden (Phinney e.a., 1997, Phinney e.a., 2001, maar zie ook Rumbaut (1994) die geen relatie vond tussen etnische identiteit en depressie).

Nu kunnen migranten echter zowel een sterke etnische identiteit ontwikkelen en zich tegelijkertijd sterk identificeren met de ontvangende samenleving. Waar Thoits (1983) stelt dat meerdere identiteiten het psychisch welzijn positief beïnvloeden (zie ook: Phinney, 2001) zou volgens Brook, Garcia en Fleming (2008) het hebben van meerdere identiteiten alleen voor een beter psychisch welzijn zorgen als de verschillende identiteiten in harmonie zijn met elkaar. Het hebben van meerdere identiteiten die met elkaar conflicteren, zorgt daarentegen voor een slechter psychisch welzijn (Brook e.a., 2008). Immers een gelijktijdige identificatie met zowel de etnische groep als met de ontvangende samenleving zou voor rolverwarring kunnen zorgen, met psychische klachten als gevolg (Bhugra, 2004; Virta e.a., 2004).

Phinney en collega's (2001: 506) opperden dat integratiebeleid dat meer de assimilatie van minderheden nastreeft in vergelijking met het multiculturalisme tot een verhoogde prevalentie van depressie onder migranten kan leiden. Onduidelijk bleef of dit volgens hen zou komen omdat in een dergelijk klimaat etnische identificatie niet meer bijdraagt aan psychisch welbevinden of dat in een 'assimilatieklimaat' minderheden zich minder sterk etnisch identificeren. Recent Nederlands onderzoek waarbij etnische en nationale identificatie als losse constructen zijn gemeten en waarin het samenspel van deze twee identiteiten met het voorkomen van depressieklachten is onderzocht, is ons onbekend.

Gegeven dat zoals gezegd het Nederlands integratiebeleid zich het laatste decennium steeds verder van het multiculturalisme heeft verwijderd en steeds meer nadruk legt op (gedwongen) culturele aanpassing, vragen wij ons af of (nu nog steeds) juist een sterke culturele gerichtheid op de eigen groep bescherming biedt tegen depressieklachten. Wij achten het aannemelijk dat - net zoals bij het zowel onderhouden van sociale contacten met leden van de etnische herkomstgroep als met autochtone Nederlanders - juist bij migranten die zich zowel met de herkomstgroep identificeren als met de ontvangende samenleving psychische problemen ontstaan als gevolg van het balanceren tussen twee culturen. Al met al, verwachten wij dat:

2a: Een sterker ontwikkelde (etnische en nationale) identiteit onder Turkse en Marokkaanse Nederlanders hangt samen met minder gerapporteerde depressieklachten.

2b: Het gelijktijdig identificeren met zowel de etnische groep als met de ontvangende samenleving verzwakt het negatieve verband tussen de mate van (etnische en nationale) identificatie en depressieklachten. 
Turkse en Marokkaanse Nederlanders van de tweede generatie voelen zich vaker Nederlands dan de eerste generatie (CBS, 2010). De tweede generatie identificeert zich bovendien minder met de etnische herkomst en meer met de ontvangende samenleving dan de eerste generatie. Het gevolg hiervan is dat zij zich ook vaker dan de eerste generatie in meer of mindere mate met beide culturen identificeren (Tolsma e.a., 2012). Indien we bevestiging vinden voor hypothese $2 \mathrm{~b}$ zouden we dus ook verwachten dat:

2c: Het rapporteren van depressieklachten hangt vooral onder de tweede generatie samen met het gelijktijdig identificeren met de etnische herkomst (van de ouders) als met de ontvangende samenleving.

Het beheersen en het gebruiken van de etnische taal (hier het Turks dan wel het Marokkaans (meer precies het Berbers of Arabisch)) kan als symbool gezien worden voor de mate van (etnische) identificatie. Omdat we in het bovenstaande een relatie tussen identiteit en depressieklachten veronderstelden, zal taalbeheersing mogelijk indirect, via etnische en nationale identificatie, een invloed hebben op het psychisch welbevinden. Onder Turkse jongeren vonden Vedder en Virta (2005) echter geen bevestiging voor dit zogenoemd ethnic identity model. Beheersing van het Nederlands noch beheersing van het Turks hing samen met etnische identificatie en daarmee indirect met psychisch welbevinden.

Taalbeheersing kan echter ook een direct effect hebben op het psychisch welbevinden. Een betere taalbeheersing vergemakkelijkt het om (beginnende) emotionele en psychische problemen onder woorden te brengen, een hulpvraag te formuleren en de weg te vinden in de (geestelijke) gezondheidszorg. Dit zal in sterkere mate gelden voor het beheersen van het Nederlands dan voor de taal van het herkomstland. Een eventueel anamnesegesprek met een (huis)arts levert meer relevante informatie indien arts en patiënt elkaar verstaan en zeker indien gebruikgemaakt wordt van Nederlandse diagnose-instrumenten neemt kans op een juiste diagnose toe met een beter begrip van het Nederlands. Verschillende organisaties reageerden dan ook onthutst toen het kabinet besloot om vanaf 1 januari 2012 de tolkenvergoeding in de gezondheidszorg af te schaffen. ${ }^{5}$ Vedder en Virta (2005) toonden onder Turkse jongeren wel een direct verband aan tussen beheersing van het Nederlands en psychisch welbevinden, maar niet tussen beheersing van het Turks. Hoewel ten tijde waarin de NELLS verzameld is de tolkenvergoeding nog niet was afgeschaft verwachten wij dat, zelfs nadat we rekening houden met etnische en nationale identificatie:

3a: Hoe beter Turkse en Marokkaanse Nederlanders de Nederlandse taal beheersen, hoe minder vaak zij depressieklachten rapporteren. 
Aangezien de tweede generatie migranten de Nederlandse taal in het algemeen beter beheersen dan de eerste generatie (Gijsberts \& Dagevos, 2009) formuleren wij tevens de hypothese dat:

$3 b$ : Het rapporteren van depressieklachten hangt vooral onder de eerste generatie 187 samen met het minder beheersen van het Nederlands. ${ }^{6}$

Uit verschillende onderzoeken komt naar voren dat religie beschermt tegen psychische problemen (Driessen, 2011; Harker, 2001; Schwadel \& Falci, 2012). De meeste Turkse en Marokkaanse migranten zijn islamitisch: van de Turkse migranten ziet $94 \%$ zichzelf als moslim, bij de Marokkaanse migranten is dat $97 \%$. Dit wil echter niet zeggen dat er geen verschillen bestaan in de religieuze praktijk tussen etnische groepen en tussen de generaties. Hoewel er sprake is van religieuze vitalisering onder de tweede generatie in Nederland, houdt de tweede generatie zich minder strikt aan de 'regels van de islam' (Maliepaard \& Gijsberts, 2012). De religieuze praktijk komt onder andere tot uiting in het wel of niet vasten tijdens de ramadan (de ramadan vormt één van de vijf zuilen van de islam), het wel of niet eten van varkensvlees (varkensvlees wordt als onrein (haram) beschouwd) en het wel of niet nuttigen van alcohol. De laatste hypothesen die uit het bovenstaande volgen luiden dan ook: 4a: Naarmate Turkse en Marokkaanse Nederlanders meer leven volgens de regels van de islam, zullen depressieklachten minder gerapporteerd worden.

4b: Het rapporteren van depressieklachten hangt vooral onder de tweede generatie samen met het minder leven volgens de regels van de islam.

\section{Data en methoden}

In dit artikel worden data van de eerste golf van de NEderlandse Levensloopstudie (NELLS, 2010) gebruikt (De Graaf e.a., 2010). Deze data zijn tussen december 2008 en mei 2010 verzameld onder etnische minderheidsgroepen en autochtonen in Nederland (14 tot 45 jaar). Er is een onderscheid gemaakt tussen allochtonen van de eerste en de tweede generatie. Om de data te verzamelen werd gebruikgemaakt van een tweedelige gestratificeerde steekproef. Het eerste gedeelte betrof een aselecte gestratificeerde steekproef van 35 gemeenten naar regio en urbanisatie. Het tweede gedeelte betrof een aselecte gestratificeerde selectie uit het bevolkingsregister, gebaseerd op leeftijd en geboorteland van de respondent en zijn of haar ouders. Respondenten van Marokkaanse en Turkse herkomst zijn oververtegenwoordigd.

De vragenlijst van NELLS bestond uit een mondeling (face-to-face) gedeelte en een schriftelijk gedeelte die de respondenten zelf moesten invullen (self-completion). Het mondelinge gedeelte richtte zich op de sociaaleconomische en sociaal-demografische achtergrond van de respon- 
dent. De schriftelijke vragenlijst had betrekking op normen en waarden, houdingen, bekwaamheid en de sociale integratie van de respondent. De respons van het onderzoek voor het mondelinge gedeelte was $52 \%$, dit is vergelijkbaar met soortgelijke surveys in Nederland. De respons was het hoogste onder Nederlanders (56\%), gevolgd door Turkse migranten $(50 \%)$ en het laagste onder Marokkaanse migranten (46\%). De reden voor de lagere respons bij de migrantengroepen is dat zij moeilijker te bereiken waren en bovendien minder vaak bereid waren om aan het onderzoek mee te werken. Er zijn ook respondenten die niet hebben deelgenomen door taalproblemen. Hoewel er wel vertaalde schriftelijke vragenlijsten beschikbaar waren, zijn er alleen Nederlandse interviewers gebruikt. In totaal werden er 5312 respondenten geïnterviewd en meer dan $92 \%$ van deze respondenten hebben naast het mondelinge interview ook de schriftelijke vragenlijst ingevuld en geretourneerd en met deze groep starten wij de databewerkingen.

\section{I Depressieklachten}

De prevalentie van depressieklachten is gemeten in het schriftelijke gedeelte van de NELLS-vragenlijst met de Center for Epidemiologic Depression Scale (CES-D). De CES-D schaal bestaat origineel uit twintig items waarvan er in de NELLS zestien zijn gebruikt. Vier items uit de originele CES-D schaal die betrekking hebben op positieve gevoelens zijn, net als in eerder onderzoek, niet gemeten (Harker, 2001). De CES-D schaal is ontwikkeld om symptomen van depressie vast te stellen in surveys voor de algemene bevolking (Radloff, 1977). De respondenten werden onder andere de volgende stellingen voorgelegd: 'In de afgelopen week: stoorde ik me aan dingen, die me gewoonlijk niet storen; had ik geen zin in eten, was mijn eetlust slecht'. De antwoordmogelijkheden waren: (1) 'zelden of nooit (minder dan $1 \mathrm{dag})$ ', (2) 'soms of weinig (1-2 dagen)', (3) 'regelmatig (3-4 dagen)' of (4) 'meestal of altijd (5-7 dagen)'. Een overzicht van alle items is opgenomen in appendix I. Van de zestien items is een somschaal geconstrueerd voor respondenten die op alle items een geldige score hadden (het aantal respondenten met één of meer ontbrekende waarden is 87 inclusief autochtonen en 55 exclusief autochtonen).

De somschaal met zestien items is volgens Schroevers e.a. (2000) een betrouwbare en valide meting van depressieklachten en zou samen één factor-dimensie vormen (onder kankerpatiënten en een gezonde referentiegroep, niet uitgesplitst naar etniciteit). Voor de vergelijking van depressieklachten tussen verschillende etnische groepen (en generaties) is het van belang dat de items in de CES-D schaal op dezelfde manier worden geïnterpreteerd. Hoewel de interne consistentie van de som- 
schaal goed was - de Cronbach's alfa van de afzonderlijke etnische groepen ligt tussen de 0.92 en 0.94 - blijken de zestien items niet binnen elke afzonderlijke etnische groep één factor-dimensie te vormen. Ook eerder onderzoek liet zien dat depressieve symptomen zich bij (oudere) Turkse en Marokkaanse migranten vaker in lichamelijke (somatische) klachten uitten dan bij (oudere) autochtone Nederlanders (Spijker e.a., 2004). ${ }^{7}$ Hoewel ook Spijker en collega's (2004) concluderen dat de somscore van de afzonderlijke items van de CES-D desondanks een betrouwbare meting vormt van symptomen van depressie, blijven we waakzaam voor mogelijke problemen met meet-inequivalentie. Additionele analyses waarbij we de somscores op de drie theoretische subdimensies (Depressed Affect, Somatic-Retarded Affect en Interpersonal Affect; Radloff, 1977) gebruikten, leiden echter niet tot andere conclusies.

\subsection{Onafhankelijke variabelen}

De eerste onafhankelijke variabele is etniciteit-naar-generatie. Wanneer respondenten niet in Nederland waren geboren, rekenen wij hen tot migranten van de eerste generatie. Respondenten die in Nederland zijn geboren en van wie ten minste één ouder in het buitenland is geboren, worden als migranten van de tweede generatie beschouwd. We onderscheiden vervolgens Turkse en Marokkaanse Nederlanders van de eerste en tweede generatie en autochtone Nederlanders. Respondenten met een andere etnische herkomst zijn verwijderd. Dit betrof 455 respondenten $(8,6 \%)$.

Een eerste indicator van sociale integratie zijn de zogenaamde 'zwakke bindingen' van migranten. Respondenten is gevraagd hoe vaak ze in de buurt en op het werk en/of op school persoonlijk contact hebben met mensen van een Nederlandse, Turkse en Marokkaanse herkomst. Er was keuze uit zeven antwoordcategorieën lopend van (0) 'nooit' tot (6) '(bijna) elke dag'. De categorie 'niet van toepassing' is samengevoegd met de categorie 'nooit'. Hiermee zijn voor de migrantengroepen vier intervalvariabelen geconstrueerd. Twee variabelen meten de zwakke bindingen met autochtone Nederlanders. Twee variabelen meten de zwakke bindingen met mensen van dezelfde etnische herkomst.

Om het aantal sterke bindingen te meten is er gevraagd naar de personen met wie respondenten in de afgelopen zes maanden belangrijke persoonlijke zaken bespraken. Respondenten konden hierbij maximaal vijf namen opgeven (dit werd slechts door 8,6\% van de respondenten gedaan). Respondenten dienden van deze personen ook de etnische achtergrond te verstrekken. Vervolgens zijn er twee variabelen geconstrueerd die respectievelijk het aantal sterke bindingen met personen van autochtone herkomst meet en het aantal sterke bindingen met leden van de eigen herkomst. ${ }^{8}$ 
Etnische en nationale identificatie, als indicatoren van culturele integratie, zijn onderzocht aan de hand van verschillende stellingen. Drie stellingen hadden betrekking op etnische identificatie: 'Ik identificeer me sterk met mijn etnische groep', 'Ik voel me echt verbonden met mijn etnische groep' en 'Mijn etnische identiteit is een belangrijk deel van mezelf. Drie stellingen hadden betrekking op identificatie met Nederland: 'Ik identificeer me sterk met Nederland', 'Ik voel me echt verbonden met Nederland' en 'Mijn Nederlandse identiteit is een belangrijk deel van mezelf'. Respondenten konden steeds aangeven of ze het met de respectievelijke stelling (1) 'zeer mee oneens' tot (5) 'zeer mee eens' waren. Met deze variabelen zijn twee schalen geconstrueerd door het gemiddelde van de drie items te nemen, voor een geldige score op de schalen moesten respondenten op twee van de drie items een geldige score hebben. De schalen geven aan in hoeverre men zich met Nederland (Cronbach's alfa is 0,86 ) dan wel het land van herkomst identificeert (Cronbach's alfa is 0,92$){ }^{9}$

De beheersing van de Nederlandse taal is bepaald met behulp van vier variabelen. Er is gevraagd hoe goed de respondent: 'iemand begrijpt die Nederlands spreekt', 'zelf Nederlands spreekt', 'iets in de Nederlandse taal leest' en 'iets in het Nederlands schrijft'. Daarbij kon hij of zij aangeven dit (1) 'niet' tot (5) 'erg goed' te kunnen. Deze items zijn samengevoegd tot een Likertschaal met een Cronbach's alfa van 0,97.10

Om te onderzoeken in hoeverre respondenten zich houden aan de regels van de islam, kregen ze vragen voorgelegd die zich richtten op religieuze gebruiken binnen de islam. Er zijn drie variabelen die de integratie in de islam meten, deze hebben betrekking op het al dan niet vasten tijdens de ramadan, het nuttigen van alcohol en varkensvlees eten. De respondenten konden aangeven dit wel te doen, niet te doen of dat het op hen niet van toepassing was. ${ }^{11}$ De betekenis van deze niet van toepassing categorie is enigszins onduidelijk, maar of respondenten voor deze categorie kozen hing niet samen met leeftijd, geslacht of denominatie (inclusief niet religieus). Respondenten met een ontbrekende waarde zijn toegevoegd aan de 'niet van toepassing' categorie, aangezien het hier per item maximaal drie respondenten betrof.

In de analyses is steeds gecontroleerd voor geslacht, leeftijd (en leeftijd-kwadraat), opleidingsniveau en arbeidsmarktpositie. Om het hoogst bereikte opleidingsniveau van een respondent te bepalen, is uitgegaan van de hoogste voltooide opleiding, ongeacht of het hier een opleiding uit het herkomstland of in Nederland betrof. Van die respondenten die momenteel nog een opleiding volgen, is de hoogst bereikte opleiding gelijkgesteld aan het huidige opleidingsniveau. Uiteindelijk bestaat deze variabele uit drie categorieën: laag opgeleiden, middelbaar opgeleiden en hoog opgeleiden. Respondenten zonder opleiding, basisonderwijs, 
lbo of mavo (of met een vergelijkbare buitenlandse opleiding) worden beschouwd als laag opgeleiden. Respondenten, welke mbo, havo of vwo hebben gevolgd (of een vergelijkbare opleiding in het buitenland), worden gezien als middelbaar opgeleiden. Respondenten worden beschouwd als hoog opgeleid indien ze een hbo-opleiding, universitaire opleiding hebben gevolgd of zijn gepromoveerd.

De arbeidsmarktpositie van respondenten is ten slotte bepaald door te kijken of zij al dan niet naar school gingen, werken, werkloos zijn en werkzoekend of werkloos maar niet werkzoekend (inactief). Alle respondenten die aangaven een voltijdsopleiding te volgen, zijn (ongeacht of zij ook betaalde arbeid verrichtten) beschouwd als schoolgaanden.

\subsection{Werkbestand en ontbrekende waarden}

Voor dit artikel zijn enkel die respondenten gebruikt die zowel de mondelinge als schriftelijke vragenlijst hadden ingevuld. Respondenten met een of meer ontbrekende waarden op items van de CES-D schaal zijn verwijderd net zoals respondenten die niet tot de autochtone, Turkse of Marokkaanse Nederlanders gerekend konden worden. Voor categorische verklarende variabelen is indien nodig een additionele categorie 'ontbrekend' aangemaakt. Respondenten met ontbrekende waarden op interval variabelen zijn uit de steekproef verwijderd. In totaal betrof dit slechts $4,6 \%$.

\section{Analyse en resultaten}

\section{I Bivariate verbanden}

Tabel 1 laat zien dat de autochtone bevolking het laagst scoort op de CES-D schaal met een gemiddelde van 4,32. Dit betekent dat depressieve klachten bij hen in vergelijking met de Turkse en Marokkaanse Nederlanders het minst vaak voorkomen. Opvallend is dat de Turkse Nederlanders van de tweede generatie het hoogste gemiddelde hebben terwijl de tweede generatie Marokkaanse Nederlanders juist het laagste gemiddelde hebben van de allochtone groepen. In tabel 1 zien we ook dat er aanzienlijke variabiliteit is in de indicatoren voor sociaal-culturele integratie. In appendix II en III zijn bovendien de samenhangen tussen etniciteit-naar-generatie en deze indicatoren weergegeven. De tweede generatie heeft meer zwakke bindingen met zowel autochtone Nederlanders als met leden van de eigen etnische groep. Daarentegen heeft de tweede generatie minder sterke bindingen met leden van de eigen groep. $\mathrm{Zij}$ identificeert zich (iets) meer met Nederland en (iets) minder met de eigen etnische herkomst. Bovendien houdt de tweede generatie zich minder 
verband

\begin{tabular}{|c|c|c|c|c|c|c|c|c|}
\hline & $\mathbf{N}$ & $\%$ & $\begin{array}{l}\text { Mini- } \\
\text { mum }\end{array}$ & $\begin{array}{l}\text { Maxi- } \\
\text { mum }\end{array}$ & $\begin{array}{l}\text { Gemid- } \\
\text { delde }\end{array}$ & $\begin{array}{l}\text { Std. } \\
\text { Devi- } \\
\text { atie }\end{array}$ & $\begin{array}{l}\text { Gemid- } \\
\text { delde } \\
\text { CES-D } \\
\text { schaal }\end{array}$ & $\begin{array}{l}\text { Std. } \\
\text { Devi- } \\
\text { atie }\end{array}$ \\
\hline \multicolumn{9}{|l|}{ Afhankelijke variabelen } \\
\hline $\begin{array}{l}\text { Depressieklachten } \\
\text { (inclusief autochtonen) }\end{array}$ & 4401 & & 0 & 48 & 5,04 & 6,93 & & \\
\hline $\begin{array}{l}\text { Depressieklachten } \\
\text { (exclusief autochtonen) }\end{array}$ & 1920 & & 0 & 48 & 5,94 & 7,81 & & \\
\hline \multicolumn{9}{|l|}{ Onafhankelijke variabelen } \\
\hline \multicolumn{9}{|l|}{ Etniciteit-naar-generatie } \\
\hline Marokkaans, eerste generatie & 617 & 32,1 & & & & & 6,02 & 8,30 \\
\hline Marokkaans, tweede generatie & 350 & 18,2 & & & & & 5,37 & 6,84 \\
\hline Turks, eerste generatie & 605 & 31,5 & & & & & 6,04 & 7,91 \\
\hline Turks, tweede generatie & 348 & 18,1 & & & & & 6,26 & $7,7 \mathrm{I}$ \\
\hline Autochtoon & 2444 & - & & & & & 4,32 & 6,04 \\
\hline \multicolumn{9}{|l|}{ Controle variabelen } \\
\hline \multicolumn{9}{|l|}{ Geslacht } \\
\hline Vrouw & 1019 & 53,1 & & & & & & \\
\hline Man & 901 & 46,9 & & & & & & \\
\hline Leeftijd $^{b}$ & & & 14 & 49 & 30,89 & 8,94 & & \\
\hline Leeftijd-kwadraat ${ }^{b}$ & & & 196 & 2401 & $1034,2 \mid$ & $54 I, 97$ & & \\
\hline \multicolumn{9}{|l|}{ Structurele kenmerken } \\
\hline \multicolumn{9}{|l|}{ Opleidingsniveau } \\
\hline Laag & 862 & 44,9 & & & & & & \\
\hline Middelbaar & 625 & 32,6 & & & & & & \\
\hline Hoog & 262 & 13,6 & & & & & & \\
\hline Ontbrekend opleiding & $|7|$ & 8,9 & & & & & & \\
\hline \multicolumn{9}{|l|}{ Arbeidsmarktpositie } \\
\hline Schoolgaand & 401 & 20,9 & & & & & & \\
\hline Werkend & 833 & 43,4 & & & & & & \\
\hline Werkloos & 149 & 7,8 & & & & & & \\
\hline Inactief & 365 & 19,0 & & & & & & \\
\hline Ontbrekend arbeidsmarktpositie & 172 & 9,0 & & & & & & \\
\hline \multicolumn{9}{|l|}{ Sociale kenmerken } \\
\hline Contact in de buurt (autochtoon) & & & 0 & 6 & 4,63 & I,7। & & \\
\hline Contact in de buurt (eigen groep) & & & 0 & 6 & 4,63 & $\mathrm{I}, 87$ & & \\
\hline $\begin{array}{l}\text { Contact op school/werk } \\
\text { (autochtonen) }\end{array}$ & & & 0 & 6 & 4,63 & 2,34 & & \\
\hline $\begin{array}{l}\text { Contact op school/werk } \\
\text { (eigen groep) }\end{array}$ & & & 0 & 6 & 4,02 & 2,52 & & \\
\hline $\begin{array}{l}\text { Aantal sterke bindingen } \\
\text { (autochtoon) }\end{array}$ & & & 0 & 5 & 0,44 & 0,83 & & \\
\hline $\begin{array}{l}\text { Aantal sterke bindingen } \\
\text { (eigen groep) }\end{array}$ & & & 0 & 5 & 1,44 & 1,19 & & \\
\hline \multicolumn{9}{|l|}{ Culturele kenmerken } \\
\hline Nationale identificatie & & & 1 & 5 & 3,65 & 0,80 & & \\
\hline
\end{tabular}




\begin{tabular}{|c|c|c|c|c|c|c|c|c|}
\hline & \multicolumn{6}{|c|}{ Descriptieve statistiek } & \multicolumn{2}{|c|}{$\begin{array}{c}\text { Bivariaat } \\
\text { verband }\end{array}$} \\
\hline & $\mathbf{N}$ & $\%$ & $\begin{array}{l}\text { Mini- } \\
\text { mum }\end{array}$ & $\begin{array}{l}\text { Maxi- } \\
\text { mum }\end{array}$ & $\begin{array}{l}\text { Gemid- } \\
\text { delde }\end{array}$ & $\begin{array}{l}\text { Std. } \\
\text { Devi- } \\
\text { atie }\end{array}$ & $\begin{array}{l}\text { Gemid- } \\
\text { delde } \\
\text { CES-D } \\
\text { schaal }\end{array}$ & $\begin{array}{c}\text { Std. } \\
\text { Devi- } \\
\text { atie }\end{array}$ \\
\hline Etnische identificatie & & & 1 & 5 & 4,06 & 0,85 & & \\
\hline Beheersen van de Nederlandse taal & & & I & 5 & 4,21 & 0,96 & & \\
\hline \multicolumn{9}{|l|}{ Vasten tijdens de ramadan } \\
\hline Ja & $|56|$ & 81,3 & & & & & & \\
\hline Nee & 329 & 17,1 & & & & & & \\
\hline Niet van toepassing & 30 & 1,6 & & & & & & \\
\hline \multicolumn{9}{|l|}{ Alcohol nuttigen } \\
\hline Ja & 448 & 23,3 & & & & & & \\
\hline Nee & 1308 & 68,1 & & & & & & \\
\hline Niet van toepassing & 164 & 8,5 & & & & & & \\
\hline \multicolumn{9}{|l|}{ Varkensvlees eten } \\
\hline Ja & 132 & 6,9 & & & & & & \\
\hline Nee & 1618 & 84,3 & & & & & & \\
\hline Niet van toepassing & 170 & 8,9 & & & & & & \\
\hline
\end{tabular}

a De descriptieve statistiek is, tenzij anders vermeld, gebaseerd op de Turkse en Marokkaanse Nederlanders, exclusief de autochtone Nederlanders.

b Hoewel de doelpopulatie 14-45 jarigen betrof, zijn doordat het veldwerk relatief lang duurde enkele respondenten ouder dan 45 geïnterviewd.

Bron: NELLS, 2010

vaak aan de regels van de islam en beheersen zij het Nederlands beter dan de eerste generatie. Verschillen tussen de etnische groepen zijn minder geprononceerd. Turkse Nederlanders zijn in sterkere mate gericht op de eigen herkomst groep in vergelijking met Marokkaanse Nederlanders (vooral de eerste generatie), maar volgen minder vaak de gebruiken van de islam. Al met al concluderen wij hieruit dat, indien deze indicatoren ook samenhangen met het voorkomen van depressieklachten, de mate van sociale-culturele integratie kan samenhangen met de verschillen in de prevalentie van depressieklachten tussen generaties en tussen etnische groepen.

\subsection{Multivariate analyses}

De eerste onderzoeksvraag richt zich op de verschillen in de prevalentie van depressieklachten tussen Marokkaanse en Turkse Nederlanders enerzijds en autochtone Nederlanders anderzijds. In tabel 2 (model 0) zien we dat migranten significant meer depressieklachten ervaren dan autochtonen. Na controle voor sociaal-demografische en structurele factoren, bekende determinanten van depressie, in model 1, blijkt dat er geen significant verschil meer bestaat in het voorkomen van depressieve symptomen tussen autochtone Nederlanders en Marokkaanse Neder- 
landers van de tweede generatie. Bij de overige etnische groepen blijft het verschil significant. Toch lijkt ook bij de Turkse Nederlanders en de eerste generatie Marokkaanse Nederlanders een deel van de verschillen samen te hangen met sociaal-demografische en structurele factoren: de effecten van etniciteit-naar-generatie zijn kleiner in model 1 dan in model 0.

Tabel 2 Verschillen in depressieklachten tussen autochtone, Turkse en Marokkaanse Nederlanders $(N=4401)$

\begin{tabular}{|c|c|c|c|c|c|c|}
\hline & \multicolumn{3}{|c|}{ Model 0} & \multicolumn{3}{|c|}{ Model I } \\
\hline & B & SE & $\mathbf{P}$ & B & SE & $\mathbf{P}$ \\
\hline Intercept & $4,32 * *$ & 0,14 & 0,00 & $3,89 *$ & 1,78 & 0,03 \\
\hline \multicolumn{7}{|c|}{ Etniciteit-naar-generatie (autochtoon = ref.) } \\
\hline Marokkaans, eerste generatie & $1,70 * *$ & 0,31 & 0,00 & $1,01 * *$ & 0,33 & 0,00 \\
\hline Marokkaans, tweede generatie & $1,05^{*}$ & 0,39 & 0,01 & 0,20 & 0,40 & 0,61 \\
\hline Turks, eerste generatie & $1,72 * *$ & 0,31 & 0,00 & $1,27^{* *}$ & 0,32 & 0,00 \\
\hline Turks, tweede generatie & $1,94 * *$ & 0,39 & 0,00 & $1,18^{* *}$ & 0,40 & 0,00 \\
\hline \multicolumn{7}{|l|}{ Controlevariabelen } \\
\hline Geslacht & & & & $-1,4 I^{* *}$ & 0,21 & 0,00 \\
\hline Leeftijd & & & & 0,09 & 0,11 & 0,43 \\
\hline Leeftijdkwadraat & & & & $0,00 * *$ & 0,00 & 0,32 \\
\hline \multicolumn{7}{|l|}{ Structurele kenmerken } \\
\hline \multicolumn{7}{|l|}{ Opleidingsniveau (laag = ref.) } \\
\hline Middelbaar & & & & $-0,6 I^{*}$ & 0,26 & 0,02 \\
\hline Hoog & & & & $-0,45$ & 0,31 & 0,15 \\
\hline Ontbrekend opleidingsniveau & & & & 0,38 & 0,49 & 0,44 \\
\hline \multicolumn{7}{|l|}{ Arbeidsmarktpositie (werkend = ref.) } \\
\hline Schoolgaand & & & & $1,36 * *$ & 0,41 & 0,00 \\
\hline Werkloos & & & & $3,51 * *$ & 0,50 & 0,00 \\
\hline Inactief & & & & $2,04 * *$ & 0,36 & 0,00 \\
\hline Ontbrekend arbeidsmarktpositie & & & & 0,75 & 0,38 & 0,05 \\
\hline $\mathrm{R}^{2}$ & 0,01 & & & 0,05 & & \\
\hline
\end{tabular}

$*=p<0,05 ; * *=p<0,0$ I; tweezijdige toetsing

Bron: NELLS, 2010

De tabellen 3 en 4 bevatten de resultaten van de analyses waarin alleen migranten zijn meegenomen. Tabel 3 maakt duidelijk dat de verschillen tussen de etnische groepen en tussen de generaties niet significant zijn, zeker nadat we rekening houden met verschillen in sociaal-demografische en structurele factoren in model 1. Aangezien we hierboven reeds opmerkten dat etnische groepen wel verschillen in de mate van sociaalculturele integratie (zie ook de appendixen II en III), is nu de vraag of deze indicatoren toch samenhangen met depressieklachten.

In tabel 4, model 2 zijn de indicatoren van sociale integratie aan model 1 van tabel 3 toegevoegd. De verwachting was dat hoe meer Turkse en Marokkaanse Nederlanders sociale relaties onderhouden, hoe min- 
Tabel 3 Verschillen in depressieklachten tussen Turkse en Marokkaanse Nederlanders $(N=1920)$

\begin{tabular}{|c|c|c|c|c|c|c|}
\hline & \multicolumn{3}{|c|}{ Model 0} & \multicolumn{3}{|c|}{ Model I } \\
\hline & B & SE & $\mathbf{P}$ & B & SE & $\mathbf{P}$ \\
\hline Intercept & $5,37 * *$ & 0,42 & 0,00 & $-2,43$ & 3,17 & 0,44 \\
\hline \multicolumn{7}{|l|}{$\begin{array}{l}\text { Etniciteit-naar-generatie } \\
\text { (Marokkaans, tweede generatie = ref.) }\end{array}$} \\
\hline Marokkaans, eerste generatie & 0,70 & 0,52 & 0,18 & 0,11 & 0,61 & 0,86 \\
\hline Turks, eerste generatie & 0,63 & 0,52 & 0,23 & 0,21 & 0,61 & 0,73 \\
\hline Turks, tweede generatie & 0,83 & 0,59 & 0,16 & 0,78 & 0,59 & 0,19 \\
\hline \multicolumn{7}{|l|}{ Controle variabelen } \\
\hline Geslacht & & & & $-1,55 * *$ & 0,37 & 0,00 \\
\hline Leeftijd & & & & $0,47^{*}$ & 0,20 & 0,02 \\
\hline Leeftijdkwadraat & & & & $-0,01 *$ & 0,00 & 0,04 \\
\hline \multicolumn{7}{|l|}{ Structurele kenmerken } \\
\hline \multicolumn{7}{|l|}{ Opleidingsniveau (laag = ref.) } \\
\hline Middelbaar & & & & $-0,12$ & 0,43 & 0,77 \\
\hline Hoog & & & & $-0,56$ & 0,58 & 0,34 \\
\hline Ontbrekend opleidingsniveau & & & & 0,00 & 0,65 & 1,00 \\
\hline \multicolumn{7}{|l|}{ Arbeidsmarktpositie (werkend = ref.) } \\
\hline Schoolgaand & & & & $2,11 *$ & 0,76 & 0,01 \\
\hline Werkloos & & & & $3,05 * *$ & 0,69 & 0,00 \\
\hline Inactief & & & & $1,16^{*}$ & 0,53 & 0,03 \\
\hline Ontbrekend arbeidsmarktpositie & & & & 0,49 & 0,65 & 0,45 \\
\hline $\mathrm{R}^{2}$ & 0,00 & & & 0,03 & & \\
\hline
\end{tabular}

$*=p<0,05 ; * *=p<0,01 ;$ tweezijdige toetsing

Bron: NELLS, 2010

der vaak zij depressieklachten zouden rapporteren (Hypothese 1a). Hierbij hebben we een onderscheid gemaakt tussen zwakke bindingen en sterke bindingen. Meer contact met autochtonen in de buurt $(b=-0,26)$, op school of op het werk $(b=-0,38)$ hangt samen met minder gerapporteerde depressieklachten. Meer contact met zwakke bindingen uit de eigen etnische groep hangt niet samen met gerapporteerde depressieklachten. Indien men een gemiddeld aantal sterke bindingen heeft met autochtone Nederlanders (leden van de eigen etnische herkomst), dan hangt het aantal sterke bindingen met leden van de eigen etnische herkomst (autochtone Nederlanders) niet samen met depressieklachten, aangezien de betreffende hoofdeffecten niet significant zijn. Hypothese 1a wordt daarmee slechts deels bevestigd.

In model 2 van tabel 4 hebben we tevens gekeken of het verband tussen de mate van sociale relaties en depressieklachten afhangt van het onderhouden van sociale relaties met zowel leden van de eigen groep als met autochtone Nederlanders. Bij de zwakke bindingen bleek dit niet het geval; de respectievelijke interactietermen zijn niet significant. De interactieterm bij sterke bindingen is wel significant $(b=-0,58)$. Respon- 
denten die (meer dan gemiddeld) diepgaande contacten onderhouden met mensen van zowel autochtone herkomst als de eigen herkomst ervaren minder depressieklachten. Dit is tegen onze verwachting in en we verwerpen daarmee hypothese $1 \mathrm{~b}$.

Model 3 van tabel 4 bevat naast de controle variabelen enkel de indicatoren van culturele integratie. De verwachting zoals geformuleerd in hypothese 2 was dat een sterk ontwikkelde etnische en nationale identiteit samenhangt met minder symptomen van depressie. Dit blijkt het geval, zoals te zien is aan de negatieve en significante parameterschattingen voor respectievelijk nationale identificatie $(b=-0,61)$ en etnische identificatie $(b=-0,63)$. Het (meer dan gemiddeld) gelijktijdig identificeren met de etnische groep als met de ontvangende samenleving verzwakt niet het negatieve verband tussen (etnische en nationale) identificatie. We dienen hypothese $2 \mathrm{~b}$ dan ook dienovereenkomstig te verwerpen. Eerder lijkt er zelfs sprake te zijn van een omgekeerd verband: een meer dan gemiddelde identificatie met zowel de eigen groep als met Nederland hangt samen met een additionele afname in gerapporteerde depressieklachten (bij eenzijdige toetsing, $b=-0,31$ ).

In hypothese $2 \mathrm{c}$ formuleerden we de verwachting dat het rapporteren van depressieklachten vooral onder de tweede generatie zou samenhangen met het gelijktijdig identificeren met de eigen etnische groep als met de ontvangende samenleving. Omdat het samengaan van een sterke etnische en nationale identiteit samenhangt met minder gerapporteerde depressieklachten, moeten we ook hypothese $2 \mathrm{c}$ verwerpen. Migranten die het Nederlands beter beheersen, hebben niet minder vaak last van depressieklachten (ook in een bivariate toetsing vinden we geen significant effect) en verklaart daarmee ook geen verschillen tussen etnische groepen en generaties. De hypothesen $3 \mathrm{a}$ en $3 \mathrm{~b}$ worden daarmee verworpen.

Een laatste indicator van culturele integratie is het leven volgens de regels van de islam. We hebben onderzocht in hoeverre respondenten die vasten tijdens de ramadan, zich onthouden van alcohol en geen varkensvlees eten, minder depressieklachten rapporteren. Geen van deze indicatoren heeft een significant effect op depressieklachten. Dit is tegen onze verwachting in en tevens een weerlegging van hypothese 4a. Ook hypothese $4 \mathrm{~b}$, waarin we veronderstellen dat depressieklachten vooral bij de tweede generatie samenhangen met het minder leven volgens de regels van de islam, kunnen we daarom niet bevestigen.

Model 4 bevat alle indicatoren van sociale en culturele integratie. We zien dat in dit model de significante effecten uit zowel model 2 als model 3 overeind blijven. 
Tabel 4 De invloed van indicatoren van sociale en culturele integratie op

depressieklachten onder Turkse en Marokkaanse Nederlanders $(N=1920)^{\mathrm{a}}$

\begin{tabular}{|c|c|c|c|c|c|c|c|c|c|}
\hline & \multicolumn{3}{|c|}{ Model 2} & \multicolumn{3}{|c|}{ Model 3} & \multicolumn{3}{|c|}{ Model 4} \\
\hline & B & SE & $\mathbf{P}$ & B & SE & $\mathbf{P}$ & B & SE & $\mathbf{P}$ \\
\hline Intercept & $-1,47$ & 3,18 & 0,64 & $-2,48$ & 3,51 & 0,48 & $-2,43$ & 3,52 & 0,49 \\
\hline \multicolumn{10}{|l|}{$\begin{array}{l}\text { Etniciteit-naar-generatie } \\
(\text { Marokkaans, tweede generatie = ref. })\end{array}$} \\
\hline Marokkaans, eerste generatie & 0,05 & 0,61 & 0,94 & 0,18 & 0,61 & 0,76 & 0,15 & 0,62 & 0,81 \\
\hline Turks, eerste generatie & 0,18 & 0,62 & 0,77 & 0,08 & 0,64 & 0,90 & 0,12 & 0,65 & 0,85 \\
\hline Turks, tweede generatie & 0,72 & 0,59 & 0,22 & 0,45 & 0,60 & 0,45 & 0,44 & 0,60 & 0,46 \\
\hline \multicolumn{10}{|l|}{ Sociale integratie } \\
\hline Contact in de buurt (autochtoon) ${ }^{b}$ & $-0,26 *$ & 0,13 & 0,04 & & & & $-0,28^{*}$ & 0,13 & 0,03 \\
\hline Contact in de buurt (eigen groep) & 0,07 & 0,12 & 0,55 & & & & 0,13 & 0,12 & 0,29 \\
\hline $\begin{array}{l}\text { Contact in de buurt (eigen groep) } \\
* \text { contact in de buurt (autochtoon) }\end{array}$ & 0,01 & 0,05 & 0,87 & & & & 0,01 & 0,05 & 0,90 \\
\hline $\begin{array}{l}\text { Contact op het werk/school } \\
\text { (autochtoon) }{ }^{\mathrm{b}}\end{array}$ & $-0,38^{*}$ & 0,17 & 0,03 & & & & $-0,40^{*}$ & 0,17 & 0,02 \\
\hline 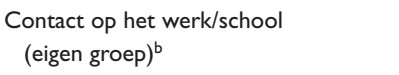 & $-0,07$ & 0,10 & 0,51 & & & & $-0,04$ & 0,10 & 0,67 \\
\hline $\begin{array}{l}\text { Contact op het werk/school } \\
\text { (autochtoon) } * \text { Contact op het werk/ } \\
\text { school (eigen groep) }\end{array}$ & $-0,01$ & 0,05 & 0,82 & & & & $-0,01$ & 0,05 & 0,77 \\
\hline Aantal sterke bindingen (autochtoon) ${ }^{\mathrm{b}}$ & $-0,32$ & 0,25 & 0,21 & & & & $-0,39$ & 0,26 & 0,12 \\
\hline Aantal sterke bindingen (eigen groep) ${ }^{b}$ & 0,01 & 0,16 & 0,95 & & & & 0,06 & 0,16 & 0,70 \\
\hline $\begin{array}{l}\text { Aantal sterke bindingen (autochtoon) } \\
\text { *Aantal sterke bindingen (eigen } \\
\text { groep) }\end{array}$ & $-0,58^{*}$ & 0,22 & 0,01 & & & & $-0,53 *$ & 0,22 & 0,01 \\
\hline \multicolumn{10}{|l|}{ Culturele integratie } \\
\hline Nationale identificatie ${ }^{b}$ & & & & $-0,61 *$ & 0,23 & 0,01 & $-0,53^{*}$ & 0,23 & 0,02 \\
\hline Etnische identificatie ${ }^{b}$ & & & & $-0,63$ ** & 0,22 & 0,00 & $-0,66^{* *}$ & 0,22 & 0,00 \\
\hline $\begin{array}{l}\text { Nationale identificatie } * \text { Etnische } \\
\text { identificatie }\end{array}$ & & & & $-0,31$ & 0,23 & 0,19 & $-0,26$ & 0,23 & 0,27 \\
\hline Beheersing van de Nederlandse taal ${ }^{\mathrm{b}}$ & & & & 0,08 & 0,23 & 0,71 & 0,26 & 0,23 & 0,26 \\
\hline \multicolumn{10}{|l|}{ Vasten tijdens de ramadan (niet $=$ ref.) } \\
\hline Wel & & & & $-0,62$ & 0,58 & 0,29 & $-0,69$ & 0,59 & 0,24 \\
\hline Niet van toepassing & & & & $-1,86$ & 1,49 & 0,21 & $-1,97$ & $\mathrm{I}, 48$ & 0,18 \\
\hline \multicolumn{10}{|l|}{ Alcohol nuttigen (wel = ref.) } \\
\hline Geen & & & & $-0,53$ & 0,52 & 0,31 & $-0,48$ & 0,52 & 0,36 \\
\hline Niet van toepassing & & & & 0,44 & $|, 2|$ & 0,72 & 0,38 & 1,21 & 0,75 \\
\hline \multicolumn{10}{|l|}{ Varkensvlees eten (wel = ref.) } \\
\hline Niet & & & & 0,82 & 0,80 & 0,31 & 0,78 & 0,81 & 0,33 \\
\hline Niet van toepassing & & & & 0,94 & 1,36 & 0,49 & 0,93 & 1,36 & 0,49 \\
\hline $\mathrm{R}^{2}$ & 0,05 & & & 0,04 & & & 0,06 & & \\
\hline
\end{tabular}

$*=p<0,05 ; * *=p<0,0$ I; tweezijdige toetsing

a Gecontroleerd voor geslacht, leeftijd, leeftijdkwadraat, opleidingsniveau en arbeidsmarktparticipatie.

b Deze variabelen zijn gecentreerd op de gemiddelde score van de steekproef.

Bron: NELLS, 2010 


\section{Conclusie en discussie}

Dit onderzoek richtte zich op de relatie tussen indicatoren van sociale en culturele integratie en symptomen van depressie bij Turkse en Marokkaanse Nederlanders. Daarbij is ten eerste gekeken naar verschillen in prevalentie van depressieklachten tussen migranten van de eerste en tweede generatie en de autochtone bevolking. Ten tweede is onderzocht in hoeverre indicatoren van sociale en culturele integratie samenhangen met depressieklachten van migranten en of deze indicatoren de geobserveerde verschillen in prevalentie van symptomen van depressie tussen de etnische groepen en generaties kunnen verklaren.

Net als eerder onderzoek (Selten \& Nolen, 2003; Selten e.a. 2007; De Wit e.a. 2008; Van der Wurff e.a. 2004) vinden we dat Turkse en Marokkaanse Nederlanders meer depressieklachten rapporteren dan autochtone Nederlanders. Het lage opleidingsniveau van migranten en hun slechte positie op de arbeidsmarkt - determinanten van depressie - verklaren voor een belangrijk deel deze verschillen. Voor Marokkaanse Nederlanders van de tweede generatie vinden we dat indien we rekening houden met deze factoren (en met leeftijd en geslacht) zij niet vaker depressieklachten rapporteren dan autochtone Nederlanders.

Hoewel er geen duidelijke verschillen zijn in de prevalentie van depressieklachten tussen de etnische groepen onderling, is vervolgens onderzocht of specifieke indicatoren van sociale en culturele integratie samenhangen met het rapporteren van depressieklachten. Turkse en Marokkaanse Nederlanders die meer contacten hebben met autochtone Nederlanders - of dit nu contact in de buurt, op school of op het werk, of goede vrienden betreft - rapporteren minder depressieklachten. Of men sociale relaties onderhoudt met leden uit de eigen etnische groep hangt niet samen met depressieklachten. Er is hierop één uitzondering: indien men reeds relatief veel sterke bindingen heeft met autochtone Nederlanders, hangt het hebben van sterke bindingen met leden uit de eigen groep wel samen met minder depressieklachten.

Turkse en Marokkaanse Nederlanders die zich sterker identificeren met Nederland rapporteren minder depressieklachten. Maar ook migranten die meer nadruk leggen op hun etnische identiteit hebben minder last van depressieklachten dan migranten die minder nadruk leggen op hun etnische identiteit. We vinden daarmee geen bevestiging voor de gedachte dat in het huidige, meer op culturele aanpassing gerichte integratieklimaat etnische identificatie meer problemen met zich meebrengt. Het lijkt noch een extra beschermende werking te bieden noch nadelig te zijn indien men zich zowel (sterk) met Nederland als (sterk) met de etnische groep identificeert. Wij vinden dus geen aanwijzingen dat het balanceren tussen twee culturen risicoverhogend werkt voor depressieklachten. Hierbij dienen we natuurlijk voorzichtigheid te betrachten bij het causaal interpreteren van onze bevindingen. 
We concluderen dus dat bepaalde indicatoren van sociaal-culturele integratie samenhangen met het rapporteren van depressieklachten. Bovendien is de tweede generatie veelal sterker gericht op de Nederlandse samenleving dan de eerste generatie en minder op de etnische herkomstgroep. Toch bleek dat, indien we rekening hielden sociaal-demografische (leeftijd en geslacht) en structurele factoren (opleidingsniveau en arbeidsmarktpositie), er geen significante verschillen tussen de generaties te bestaan in symptomen van depressie.

\section{Noten}

1. Roos van der Zwan schreef deze bijdrage gedurende het honoursprogramma dat zij volgde tijdens haar bachelor studie sociologie aan de Radboud Universiteit Nijmegen. Jochem Tolsma is als universitair docent verbonden aan de sectie sociologie van de Radboud Universiteit Nijmegen (ICS/ NISCO). Richt correspondentie aan: Jochem Tolsma, Radboud Universiteit Nijmegen, Sectie sociologie, Postbus 9104, 6500 HE Nijmegen. Email: J.tolsma@maw.ru.nl.

2. Volgens de gebruikte definitie in dit artikel zijn tweede-generatie-migranten de kinderen van eerste-generatie-migranten. Zij zijn zelf geboren in Nederland. De term tweede-generatie-migrant is dus enigszins misleidend.

3. Er is wel consensus dat juist gemarginaliseerde migranten, migranten die niet gericht zijn op hun eigen etnische cultuur noch participeren in de ontvangende samenleving, het vaakst psychische klachten vertonen.

4. Virta, Sam \& Westin (2004) zien juist de vier door Berry $(1997,2005)$ onderscheidden acculturatiestrategieën (assimilatie, integratie, marginalisatie en separatie) als een aparte interculturele factor die naast (etnische en nationale) identificatie en ervaren discriminatie van invloed zouden kunnen zijn op het psychisch welbevinden.

5. Zie bijvoorbeeld: http://www.psy.nl/meer-nieuws/dossier/Artikel/afschaffen-tolkenvergoeding-zorgt-voor-chaos/ en: http://knmg.artsennet.nl/Nieuws/Nieuwsarchief/Nieuwsbericht-1/Einde-tolkenvergoeding-geef-hier-uw-knelpunten-en-tipsdoor.htm

6. Hypothesen over het beheersen van de etnische taal ontbreken, aangezien het NELLS hier geen informatie over bevat.

7. De factorstructuur bepaald met exploratieve Principale Componentenanalyse bleek niet consistent tussen etnische groepen en binnen etnische groepen tussen generaties. We vonden één dimensie bij de eerste generatie Marokkaanse Nederlanders, drie dimensies bij de tweede generatie Marokkaanse Nederlanders en twee dimensies bij de autochtone en Turkse Nederlanders. De Cronbach's alfa is 0,93 voor alle etnische groepen samen en 0,94 voor alleen de migrantengroepen. De Cronbach's alfa is voor de autochtonen 0,92, voor de Marokkaanse migranten van de eerste en tweede generatie respectievelijk 0,94 en 0,92 en voor de Turkse migranten van de eerste en tweede generatie respectievelijk 0,94 en 0,93.

8. Er is gebruikgemaakt van de ruwe waarden. Additionele analyses waarbij deze zijn gedummificeerd ( 0 versus 1 of meer) leiden tot identieke resultaten.

9. De Cronbach's alfa's voor identificatie met Nederland en met het land van herkomst zijn respectievelijk: 0,87 en 0,90 voor Marokkaanse Nederlanders van de eerste generatie; 0,89 en 0,92 voor Marokkaanse Nederlanders van de tweede generatie; 0,84 en 0,92 voor Turkse Nederlanders van de eerste generatie; en 0,85 en 0,94 voor Turkse Nederlanders van de tweede generatie. 
10. De Cronbach's alfa voor deze schaal is 0,96 voor Marokkaanse migranten van de eerste generatie, 0,90 voor Marokkaanse migranten van de tweede generatie, 0,96 voor Turkse migranten van de eerste generatie en 0,96 voor Turkse migranten van de tweede generatie.

11. De categorie 'niet van toepassing' behorende bij de items 'alcohol drinken' en 'varkensvlees eten' bevatte ongeveer $8,5 \%$ van de respondenten. Bij het item 'vasten' betrof dit $1,5 \%$.

\section{Literatuur}

Aichberger, M.C., Schouler-Ocak, M., Mundt, A., Busch, M.A., Nickels, E., Heimann, H.M., Ströhle, A., Reischies, F.M., Heinz, A. \& Rapp, M.A. (2010). Depression in middle-aged and older first generation migrants in Europe: Results from the Survey of Health, Ageing and Retirement in Europe (SHARE). European Psychiatry, 25, 468-475.

American Psychiatric Association (1994). Diagnostic and statistical manual of mental disorders, 4th edn. American Psychiatric Press, Washington, DC.

Bengi-Arslan, L., Verhulst, F.C. \& Crijnen, A.A.M. (2002). Prevalence and determinants of minor psychiatric disorder in Turkish immigrants living in the Netherlands. Social Psychiatry and Psychiatric Epidemiology, 37, 118-124.

Berkman, L.F., Glass, T., Brissette, I. \& Seeman, T.E. (2000). From social integration to health: Durkheim in the new millennium. Social Science \& Medicine, 51, 843-857.

Berry, J.W. (1997). Immigration, acculturation, and adaption. Applied Psychology: An International Review, 46, 5-68.

Berry, J.W. (2005). Acculturation: Living successfully in two cultures. International Journal of Intercultural Relations, 29, 697-712.

Bhugra, D. (2004). Migration and mental health. Acta Psychiatrica Scandinavia, 109, 243-258.

Brook, A.T., Garcia, J. \& Fleming, A. (2008). The effects of multiple identities on psychological well-being. Personality and Social Psychology Bulletin, 34, 1588-1600.

Brown, R. (2000). Social identity theory: Past achievements, current problems and future challenges. European Journal of Social Psychology, 30 (6), 745-778.

Carta, M.G., Bernal, M., Hardoy, M.C., Haro-Abad, J.M. and the "Report on the mental health in Europe" working group. (2005). Migration and mental health in Europe (the state of the mental health in Europe working group: Appendix I). Clinical Practice and Epidemiology in Mental Health, 1.

Centraal Bureau voor de Statistiek. (CBS) (2010). Jaarrapport Integratie 2010. Den Haag: Centraal Bureau voor de Statistiek. 
Coenders, M., Lubbers, M., Scheepers, P., \& Verkuyten, M. (2008). More than two decades of changing ethnic attitudes in the Netherlands. Journal of Social Issues, 64, 269-285.

Cohen, S. (2004). Social relationships and health. American Psychologist, 59, 676-684.

Dagevos, J. (2001). Perspectief op integratie. Over de sociaal-culturele en structurele integratie van etnische minderheden in Nederland. Den Haag: Wetenschappelijke Raad voor het Regeringsbeleid.

Driessen, M. (2011). Geestelijke ongezondheid in Nederland in kaart gebracht. Een beschrijving van MHI-5 in de gezondheidsmodule van het permanent onderzoek leefsituatie. Den Haag: Centraal Bureau voor de Statistiek.

Durkheim, E. (1951 [1897]). Suicide: A study in sociology. New York: Free.

Entzinger, H. (2003). The rise and fall of multiculturalism: The case of the Netherlands. In C. Joppke \& E. Morawska (Eds.), Toward assimilation and citizenship (pp. 59-86). Basingstoke: Palgrave Macmillan.

Gijsberts, M. \& Dagevos, J. (2009) Jaarrapport Integratie 2009. Den Haag: Sociaal en Cultureel Planbureau.

Goode, W.J. (1960). A theory of role strain. American Sociological Review, 25, 483-496.

Graaf, P.M. de, Kalmijn, M., Kraaykamp, G. \& Monden, C.W.S. (2010). Design and content of the NEtherlands Longitudinal Lifecourse Study (NELLS). Research report. Tilburg University \& Radboud University Nijmegen, Netherlands.

Harker, K. (2001). Immigrant generation, assimilation, and adolescent psychological well-being. Social Forces, 79, 969-1004.

Janssen, M.M.M., Verhulst, F.C., Bengi-Arslan, L., Erol, N., Salter, C.J., \& Crijnen, A.A.M. (2004). Comparison of self-reported emotional and behavioral problems in Turkish immigrant, Dutch and Turkish adolescents. Social Psychiatry and Psychiatric Epidemiology, 39, 133-140.

Kawachi, I., \& Berkman, L.F. (2001). Social ties and mental health. Journal of Urban health, 78, 458-467.

Koneru, V.K., Weisman de Mamani, A.G., Flynn, P.M. \& Betancourt, H. (2007). Acculturation and mental health: Current findings and recommendations for future research. Applied and Preventive Psychology, 12, 76-76.

Maliepaard, M. \& Gijsberts, M. (2012). Moslims in Nederland 2012. Den Haag: Sociaal en Cultureel Planbureau.

Maliepaard, M., Lubbers, M. \& Gijsberts. (2010). Generational differences in ethnic and religious attachment and their interrelation. A study among Muslim minorities in the Netherlands. Ethnic and Racial Studies, 33, 451-472.

Ministerie VROM/WWI. (2007). Integratienota 2007-2011. Zorg dat je erbij hoort! Retrieved 28-02-2013, from http://www.vrom.nl/pagina.html?id= $2706 \& \mathrm{sp}=2 \& d n=w 1009$. 
Missine, S. \& Bracke, P. (2012). Depressive symptoms among immigrants and ethnic minorities: A population based study in 23 European countries. Social Psychiatry Psychiatric Epidemiology, 47, 97-109.

Peirce, R.S., Frone, M.R., Russell, M., Cooper, M.L. \& Mudar, P. (2000). A longitudinal model of social contact, social support, depression, and alcohol use. Healthy Psychology, 19, 28-38.

Phinney, J.S., Cantu, C.L., \& Kurtz, D.A. (1997). Ethnic and American identity as predictors of self-esteem among African American, Latino, and White adolescents. Journal of Youth and Adolescence, 26, 165-185.

Phinney, J.S., Horenczyk, G., Liebkind, K., \& Vedder, P. (2001). Ethnic identity, immigration, and well-being: An interactional perspective. Journal of Social issues, 57, 493-510.

Radloff, L.S. (1977). The CES-D scale: A self report depression scale for research in the general population. Applied Psychological Measurement, 1, 385-401.

Rudmin, F.W. \& Ahmadzadeh (2001). Psychometric critique of acculturation psychology: The case of Iranian migrants in Norway. Scandinavian Journal of Psychology, 42, 41-56.

Rumbaut, R. (1994). The crucible within: Ethnic identity, self-esteem, and segmented assimilation among children of immigrants. International Migration Review, 28, 748-794.

Schroevers, M.J., Sandman, R., Sonderen, van E. \& Ranchor, A.V. (2000). The evaluation of the Center for Epidemiologic Studies Depression (CES-D) scale: Depressed and positive affect in cancer patients and healthy reference subjects. Quality of Life Research, 9, 1015-1029.

Schwadel, P. \& Falci, C.D. (2012). Interactive effects of church attendance and religious tradition on depressive symptoms and positive affect. Society and Mental Health, 2, 21-34.

Seeman, T.E. (1996). Social ties and health: The benefits of social integration. Annals of Epidemiology, 6, 442-451.

Selten, J.P., Os, van J. \& Nolen, W.A. (2003). First admissions for mood disorders in immigrants to the Netherlands. Social Psychiatry Psychiatric Epidemiology, 38, 547-550.

Selten, J.-P., Laan, W., Kupka, R., Smeets, H.M. \& Os, van J. (2012). Risk of psychiatric treatment for mood disorders and psychotic disorders among migrants and Dutch nationals in Utrecht, The Netherlands. Soc. Psychiatry Psychiatric Epidemiology, 47, 271-278.

Sevincer, T., Daldal, A., Yabas, G. et al. (2010, 10 Januari). Manifest TurksNederlandse professionals: Problematiek jongeren zeer verontrustend. de Volkskrant. Retrieved 11-01-2011, from: http://www.volkskrant. nl/vk/nl/2686/Binnenland/article/detail/1790349/2011/01/10/ManifestTurks-Nederlandse-professionals-Problematiek-jongeren-zeer-verontrustend.dhtml. 
Sociaal en Cultureel Planbureau. (SCP) (2002). Rapportage Jeugd 2002. Den Haag: Sociaal en Cultureel Planbureau.

Spijker, J., Wurff F.B. van der, Poort, E.C., Smits, C.H.M., Verhoeff, A.P. \& Beekman, A.T.F. (2004). Depression in first generation labour migrants in Western Europe: The utility of the Center for Epidemiologic Studies Depression Scale (CES-D). International Journal of Geriatric Psychiatry, 19, 538-544.

Swinnen, S.G.H.A. \& Selten, J.-P. (2007). Mood disorders and migration: Meta-analysis. The British Journal of Psychiatry, 190, 6-10.

Tajfel, H., \& Turner, J.C. (1979). An integrative theory of intergroup conflict. The Social Psychology of Intergroup Relations, 33, 47.

Thoits, P.A. (1983). Multiple identities and psychological well-being: A reformulation and test of the social isolations hypothesis. American Sociological Review, 48, 174-187.

Tolsma, J., Lubbers, M. \& Gijsberts, M. (2012). Education and cultural integration among ethnic minorities and natives in the Netherlands: A test of the integration paradox. Journal of Ethnic and Migration Studies, 38, 793-813.

Umaña-Taylor, A.J., Diversi, M., \& Fine, M.A. (2002). Ethnic identity and self-esteem of Latino adolescents distinctions among the Latino populations. Journal of Adolescent Research, 17, 303-327.

Vedder, P. \& Virta, E. (2005). Language, ethnic identity, and the adaption of Turkish immigrant youth in the Netherlands and Sweden. International journal of intercultural relations, 29, 317-337.

Virta, E., Sam, D.L. \& Westin, C. (2004). Adolescents with Turkish background in Norway and Sweden: A comparative study of their psychological adaption. Scandinavian Journal of Psychology, 45, 15-25.

Wit, M.A.S. de, Tuinebreijer, W.C., Dekker, J., Beekman, A.T.F., Gorissen, Schrier, A.C., W.H.M., Penninx, B.W., Komproe, I.H., \& Verhoeff, A.P. (2008). Depressive and anxiety disorders in different ethnic groups. A population based study among native Dutch, and Turkish, Moroccan and Surinamese migrants in Amsterdam. Social Psychiatry and Psychiatric Epidemiology, 43, 905-912.

World Health Organization (1993). The ICD-10 classification of mental and behavioural disorders: Diagnostic criteria for research. Geneva: World Health Organization.

Wurff, F.B. van der, Beekman, A.T.F., Dijkshoorn, H., Spijker, J.A., Smits, C.H.M., Stek, M.L. \& Verhoeff, A.P. (2004). Prevalence and risk-factors for depression in elderly Turkish and Moroccan migrants in the Netherlands. Journal of Affective Disorders, 83, 33-41. 


\section{Appendix I De CES-D schaal}

Wilt $\mathrm{u}$ aangeven achter elke uitspraak welk antwoord het beste uw gevoel of gedrag van de afgelopen week weergeeft. In de afgelopen week...

Theoretische dimensie vol- Theoretische dimensies Items

gens Schroevers e.a. (2000) volgens Radloff (1977)

In de afgelopen week...

Depressed Affect Depressed Affect

- bleef ik maar in de put zitten, zelfs als familie of vrienden probeerden me er uit te halen.

- voelde ik me gedeprimeerd.

- vond ik mijn leven een mislukking.

- voelde ik me bang.

- voelde ik me eenzaam.

- had ik huilbuien.

- was ik treurig.

Somatic-Retarded Affect

- stoorde ik me aan dingen, die me gewoonlijk niet storen.

- had ik geen zin in eten, was mijn eetlust slecht.

- had ik moeite mijn gedachten bij mijn bezigheden te houden.

- had ik het gevoel dat alles wat ik deed me moeite kostte.

- sliep ik onrustig.

- praatte ik minder dan gewoonlijk.

- kon ik maar niet op gang komen.

Interpersonal Affect

- waren de mensen onaardig.

- had ik het gevoel dat mensen me niet aardig vonden.

Positive Affect'

Positive Affect'

- voelde ik me evenveel waard als ieder ander.

- had ik goede hoop voor de toekomst.

- was ik gelukkig.

- had ik plezier in het leven.

I Deze items zijn niet in het NELLS opgenomen

De gebruikte antwoordcategorieën zijn:

1. Zelden of nooit (minder dan $1 \mathrm{dag}$ )

2. Soms of weinig (1-2 dagen)

3. Regelmatig (3-4 dagen)

4. Meestal of altijd (5-7 dagen) 
Appendix II Samenhang tussen etniciteit-naar-generatie en intervalvariabelen (One way Anova toets)

\begin{tabular}{lccccc}
\hline & $\begin{array}{c}\text { Marok- } \\
\text { kaans, } \\
\text { eerste } \\
\text { generatie }\end{array}$ & $\begin{array}{c}\text { Marok- } \\
\text { kaans, } \\
\text { tweede } \\
\text { generatie }\end{array}$ & $\begin{array}{c}\text { Turks, } \\
\text { eerste } \\
\text { generatie }\end{array}$ & $\begin{array}{c}\text { Turks, } \\
\text { tweede } \\
\text { generatie }\end{array}$ & F \\
\hline Contact in de buurt (autochtoon) & 4,49 & 4,85 & 4,52 & 4,87 & $6,63^{* *}$ \\
Contact in de buurt (eigen groep) & $4,5 \mathrm{I}$ & 4,83 & 4,56 & 4,76 & $2,99^{*}$ \\
Contact op het werk/school (autochtoon) & 4,12 & 5,34 & 4,43 & 5,16 & $29,14^{* *}$ \\
Contact op het werk/school (eigen groep) & 3,61 & 4,60 & 3,94 & 4,34 & $14,02^{* *}$ \\
Aantal sterke bindingen (autochtoon) & 0,27 & 0,67 & 0,30 & 0,74 & $39,50^{* *}$ \\
Aantal sterke bindingen (eigen groep) & 1,38 & 1,29 & 1,61 & 1,43 & $6,54^{* *}$ \\
Nationale identificatie & 3,73 & 3,77 & 3,50 & 3,67 & $12,1 I^{* *}$ \\
Etnische identificatie & 4,08 & 4,03 & 4,11 & 3,94 & $2,98^{*}$ \\
Beheersen van de Nederlandse taal & 4,03 & 4,83 & 3,80 & 4,64 & $142,24^{* *}$ \\
\hline
\end{tabular}

$*=p<0,05 ; * *=p<0,01$

Bron: NELLS, 2010

Appendix III Samenhang tussen etniciteit-naar-generatie en islamitische gebruiken (\%)

\begin{tabular}{lcccccc}
\hline & $\begin{array}{c}\text { Marok- } \\
\text { kaans, } \\
\text { eerste } \\
\text { generatie }\end{array}$ & $\begin{array}{c}\text { Marok- } \\
\text { kaans, } \\
\text { tweede } \\
\text { generatie }\end{array}$ & $\begin{array}{c}\text { Turks, } \\
\text { eerste } \\
\text { generatie }\end{array}$ & $\begin{array}{c}\text { Turks, } \\
\text { tweede } \\
\text { generatie }\end{array}$ & Totaal & $\begin{array}{c}\text { Chi- } \\
\text { kwadraat }\end{array}$ \\
\hline Vasten tijdens de ramadan & 92,7 & 90,3 & 71,6 & 69,0 & 81,3 & $145,364^{* *}$ \\
Ja & 6,8 & 8,6 & 25,8 & 29,0 & 17,1 & \\
Nee & 0,5 & 1,1 & 2,6 & 2,0 & 1,6 & \\
Niet van & & & & & & \\
$\quad$ toepassing & 13,8 & 15,7 & 31,4 & 33,9 & 23,3 & $93,808^{* * *}$ \\
Alcohol nuttigen & 77,6 & 75,4 & 61,7 & 55,2 & 68,1 & \\
Ja & 8,6 & 8,9 & 6,9 & 10,9 & 8,5 & \\
Nee & & & & & & \\
Niet van & & & & & & \\
$\quad$ toepassing & 3,4 & 5,4 & 9,6 & 9,8 & 6,9 & \\
Varkensvlees eten & 87,2 & 85,7 & 83,3 & 79,3 & 84,3 & \\
Ja & 9,4 & 8,9 & 7,1 & 10,9 & 8,9 & \\
Nee & & & & & \\
Niet van & & & & & \\
$\quad$ toepassing & & & & & \\
\hline
\end{tabular}

$*=p<0,05 ; * *=p<0,0$ I

Bron: NELLS, 2010 